\title{
Red Moon: Notes on the Craft of the Firekeeper in the Canoe Tribes of Tierra del Fuego
}

\section{From Los Que Llegamos Mas Lejos}

The Yahgans, a people of the coast, navigators and fishermen, would never make a new fire. From as far back as their memory could go, they have always kept the same flame burning. Each hearth on the coast, each coal on board the canoes, was a new incarnation of that primeval fire. Every firekeeper inherited a flame, alive as if it had just been born, and he cared for it, and shared it when necessary. But he never-not even when lightning changed the forest into a river of flames, not even when the tribe's enemies sent a deluge of burning arrows onto their huts, not even when the missionaries showed them, with their contemptuous arrogance, a mere box of matches-never let it die.

In the Yahgan language, the name for "Firekeeper" is "protector of the ocean moon." It isn't the moon in the sky, mistress of blood and tides. It is the minute red moon that, at the end of the evening storm, one finally sees rise and set from a distance, directing the canoe that brings back the survivors.

Hypothesis on the use of the fire the Yahgans carried in their canoes, put forth by the Salesian missionary Don Bartolomeo Anchieta:

The fire was essential to help them endure the severity of navigating leeward of that polar wind.

Having a fire present gave tranquility to those navigators always afraid of getting lost or wrecking on a deserted island, or discovering on their return that the rain or their enemies had extinguished the great fire on the coast.

Fire was the image of the divine. Moreover, it was that very god that accompanied the fishermen out at sea. Considered the fourth crew member, the fire was honored like one of those ancient chiefs that, even though unable to hold a sword or shoot an arrow, makes 
the enemy-in this case the sea, the wind, the dreadful tempestsfall back in its presence.

Carrying fire in the canoe was a custom as old as the very idea of the divine. The Yahgans, Father Anchieta points out, were as accustomed to seeing a fire in their canoes, as the sea beneath the keel, the sky above, and the coast fore and the horizon of the Atlantic aft; and be it for fear or laziness, they never wondered about the origins of those things.

The Yahgans considered all of these ponderings, like us, plausible and convincing, although only partially satisfactory. The real reason for the presence of fire in the canoes corresponds, perhaps, to a logic that we have forever lost, and that, be it as it may, has nothing to do with the utilitarian principles of our time.

The fire was carried in the very center of the canoe, in a small hearth made of stone. The rock from which this hearth came was called Wullaillu* and it could only be found on an uninhabited island in the immense Fuegian archipelago whose secret location would be revealed to the apprentice during the funeral ceremony of the master firekeeper, and usually in the coldest of winter.

The tribal elders stayed in custody of the fire of the deceased, and the young apprentice, alone in his canoe, entered the labyrinth of islands and canals with understandable unrest: because the Yahgans were true amphibians, he was not so menaced by the ferocity of the water as much as he was by the complexity of the journey before him, a journey that could freeze him to death if it took more time than necessary. After that, the exhaustion from rowing was overtaken by that of mining the rock from the seam, that strange gray seam that, nibbled away by generation after generation of firekeepers, was hardly visible at the back of the cave infested with beasts and vermin. Once he had excavated the block that would accompany him for the rest of his life, the apprentice would drink a narcotic concoction that, in exact dosage, would help him sleep until the next sunrise. During this night, with his stone as a pillow

\footnotetext{
*Wullaillu: from "wu," stone and "llaillu," "parents." Marina Isaieva notes that it shouldn't be translated, like Father Anchieta did, as "stone of the parents," but "parent stone," in the sense of "pair of progenitors," a kind of androgynous force capable of regenerating itself continuously. Furthermore, it should be noted that in Yahga, words lack gender, in the way that the idea of a stone, like any other idea is, in and of itself, neutral and, in a certain way, androgynous.
} 
and twenty wolves sniffing at his restless eyes, he had a vision that revealed a name by which the tribe would distinguish him among his sacred lineage.

If everything went well, the apprentice would spot the beach by midday, just as the cadaver of the old firekeeper was placed on top of the pyre. He would disembark amidst the smoke, show to the bereaved his piece of wullaillu, and reveal to the shaman his new name; and the shaman, after shouting it four times, once to each corner of the sky, would pour the fire of the dead into this new stone that only, with the passage of years, would acquire its characteristic hollow. For this reason, comments Pastor Whirling, the first years of the novice firekeeper were always very trying: the fire tended to capsize or slip out of the hearth with each heavy lurch of the canoe, and frequently the firekeeper had to catch it with his own hands, or his feet and, if the squall demanded that he take up the oars, even pick it up with his teeth. As a result, it is said that every firekeeper carried with him the history of his days tattooed into his flesh, concealed in his ashes.

Once the consecration ceremony of the apprentice was over, the funeral rites of the old master also came to a close. Performing a curious fire dance, the women put the ashes of the dead in the empty fire stone, the stone that once again was placed in the center of the canoe, the canoe that four swimmers hauled beyond the reef and left to drift. The shaman sang on the coast and the entire community watched the dead lose itself on its way to the Island of the Invisible, where the dead would read in the ashes of the old man the news of our steps through the world, the honest and bitter truth of our adventures.

Translated from the Spanish by Curtis Bauer 